\title{
Case studies of circular shaft construction
} in London

1 Njemile E. Faustin PhD, CEng, MICE

PhD Researcher, Department of Engineering, University of Cambridge, Cambridge, UK (corresponding author: nef22@cantab.net) (Orcid:0000-0001-5844-5633)

2 Mohammed Z. E. B. Elshafie PhD

Senior Lecturer in Construction Engineering, Laing O'Rourke Centre

for Construction Engineering \& Technology, Department of

Engineering, University of Cambridge, Cambridge, UK

(Orcid:0000-0001-8307-7115)
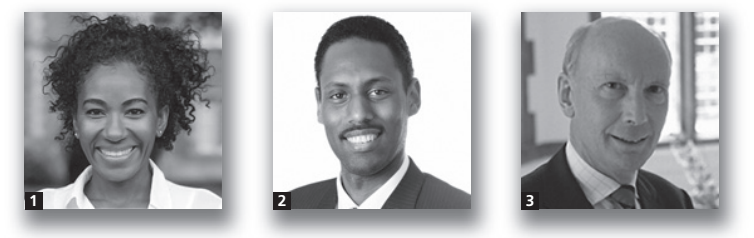

3 Robert J. Mair CBE, FREng, FICE, FRS

Sir Kirby Laing Emeritus Professor of Civil Engineering, University of Cambridge, Cambridge, UK

At present, there are few well-documented case studies of circular shaft construction, making it difficult for designers to estimate reliable ground movements arising from such construction. This paper describes field observations of ground surface settlement assembled during the construction of $\mathbf{2 7}$ circular shafts built for three major tunnelling projects in London: Crossrail, National Grid's London Power Tunnels project and Transport for London's Northern line extension. Two categories of shaft construction were identified: support before excavation (SBE) and excavation before support (EBS). For the SBE category, the shaft was first supported by pre-installed walls followed by excavation of the soil between the pre-installed walls. For the EBS category, the ground was progressively excavated in sections followed by construction of the shaft lining. Interpretation of the field observations showed the importance of the shaft construction method on ground movements. Settlements were much more significant for EBS shaft construction than for SBE shaft excavation, although settlement arising from the installation of pre-installed walls or dewatering operations should not be overlooked. Normalised charts are presented to help the industry make estimates of settlements due to circular shaft construction in London, with due consideration for different shaft geometries and construction methods.

\section{Notation}

D diameter

$H \quad$ excavation depth

$S_{\mathrm{v}} \quad$ settlement

$x \quad$ distance from shaft wall

$\alpha \quad$ empirical constant from New and Bowers (1994)

\section{Introduction}

There is great uncertainty regarding the magnitude and extent of ground movements arising from circular shaft construction. Such movements occur during the installation of pre-installed shaft linings and during excavation of the shaft. Other factors, such as the presence of soft ground or dewatering, can also cause ground movement. Data obtained during the construction of diaphragm wall shafts for the Dublin Port tunnel (Menkiti and Long, 2015) and Crossrail (Faustin et al., 2017) show that dewatering settlements can be much more significant than excavation-induced settlement.

The limited number of well-documented case studies on circular shafts makes proper investigation into the parameters influencing shaft construction ground movements, including the potential influence of the shaft construction category, very challenging. Estimates of ground movements in the UK to date are based mainly on observations from the excavation of the Heathrow Express trial tunnel (New and Bowers, 1994) or obtained from finite-element analyses. However, finite-element results are often not validated against field observations and the settlement prediction method of New and Bowers (1994) is only applicable to shafts of a similar size and construction approach to the Heathrow Express shaft. Designers thus conservatively account for these shortcomings, which can have a direct effect on the cost of tunnelling projects. For example, protective measures that may not necessarily be needed are sometimes implemented for nearby buried utility pipelines and buildings.

In recent years, several circular shafts have been constructed in London to facilitate tunnelling works for transportation and electricity infrastructure projects. The geometry of these shafts ranged from $5 \mathrm{~m}$ to $30 \mathrm{~m}$ in diameter and $15 \mathrm{~m}$ to $44 \mathrm{~m}$ in depth. In the study presented in this paper, ground surface 
settlements from precise levelling pins positioned around 27 case study shafts were assembled and carefully examined. Very little information was available regarding horizontal movement of the ground or of the shaft lining and hence these measurements are not included in this paper. Two distinct categories of circular shaft construction were identified and field observations of surface settlement are presented in simple normalised charts that could be useful to a wide range of construction professionals.

\subsection{Published settlements during excavation of circular shafts}

Ground surface settlements during the excavation of four circular shafts, reported by Wong and Kaiser (1988), New and Bowers (1994), Muramatsu and Abe (1996) and Schwamb et al. (2016), are shown in Figure 1. Due to the limited range of excavation depth to shaft diameter ratios $(H / D)$ it was thought more reasonable to present the data as plots of settlement normalised by the shaft excavation depth $\left(S_{\mathrm{v}} / H\right)$ against distance from the shaft also normalised by the shaft excavation depth $(x / H)$ for different ground conditions.

A maximum settlement of approximately $0.01 \%$ of the shaft excavation depth (i.e. $0 \cdot 01 \% H$ ) during the excavation of diaphragm wall shafts was reported by Muramatsu and Abe (1996) and Schwamb et al. (2016). In contrast, the maximum settlements reported by Wong and Kaiser (1988) and New and Bowers (1994) were at least four times greater, $0 \cdot 04 \% \mathrm{H}$ and $0.06 \% H$, respectively. This variability in maximum settlement is likely to be due to different ground conditions and different shaft construction categories.

Figure 1 also shows that the settlements reduce to zero at a distance of $0.4 \mathrm{H}$ to $1.0 \mathrm{H}$ from the edge of the shaft. This zone of extent could be influenced by the ground conditions, shaft construction category and the diameter of the shaft.

\subsection{Existing ground movement prediction models for circular shafts}

New and Bowers (1994) proposed an equation to predict settlement based on field observations during excavation of the $11 \mathrm{~m}$ dia. and $26 \mathrm{~m}$ deep Heathrow Express shaft in London Clay. The shaft was constructed progressively by concurrent excavation of the ground and erection of the shaft lining (precast segments for $16 \mathrm{~m}$ followed by a sprayed concrete lining (SCL) for a further $10 \mathrm{~m}$ ). The curve fitted to the field measurements, shown in Figure 1(c), is described by

1. $S_{\mathrm{v}}=\frac{\alpha(H-x)^{2}}{H}$

where $S_{\mathrm{v}}$ is the settlement at a distance $x$ from the shaft wall, $H$ is the shaft excavation depth and $\alpha$ is an empirical constant dependent on the ground conditions and shaft

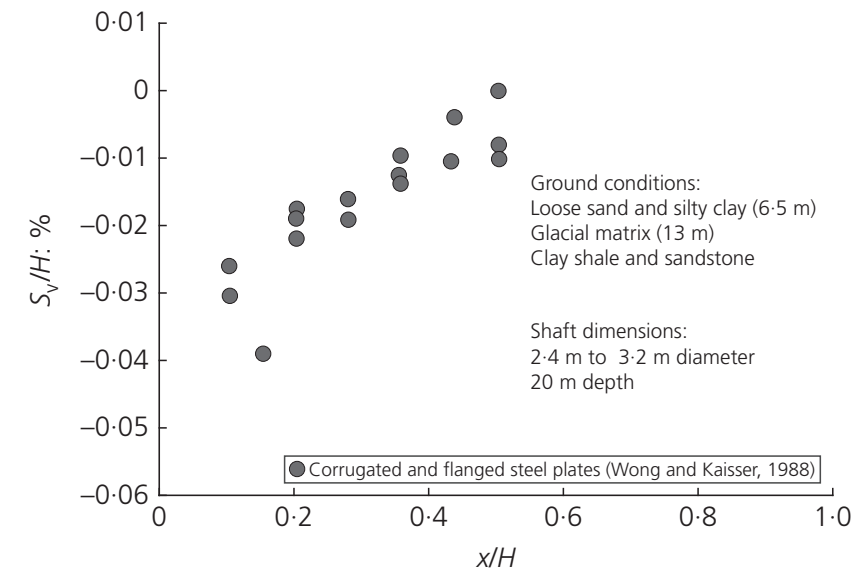

(a)

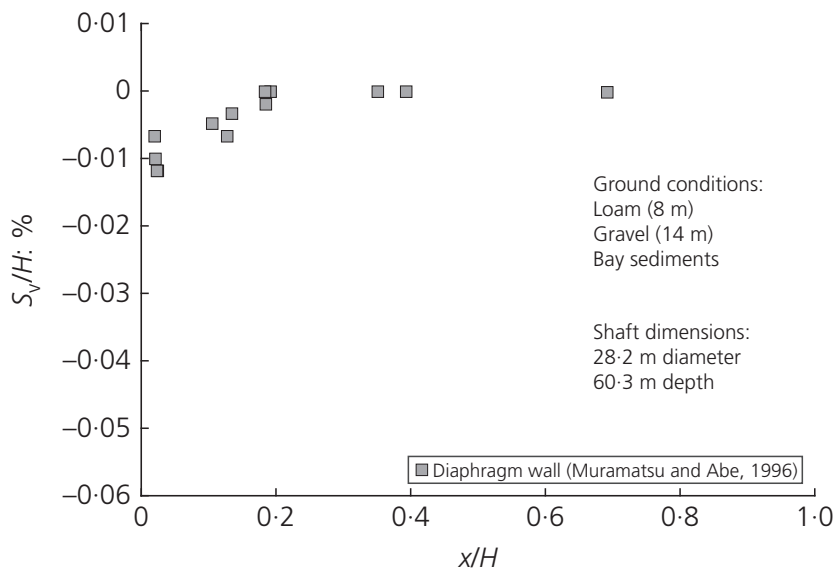

(b)

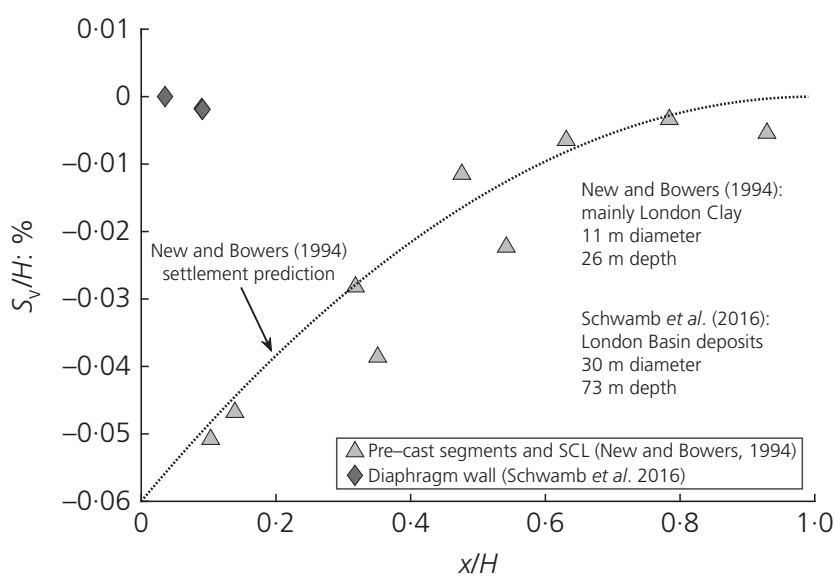

(c)

Figure 1. Comparison of published settlements during excavation of circular shafts in different ground conditions: (a) Sand and Edmonton Till; (b) Loam and Gravel; (c) London Basin deposits

construction method. The recommended value for $\alpha$ of 0.0006 indicates that the maximum settlement induced in the ground around the shaft is $0.06 \%$ of the shaft excavation depth (i.e. $S_{\mathrm{v}, \max }=0.06 \% H$ ). 
Equation 1 provides a useful estimate of the settlement that may occur during the excavation of circular shafts in clay that have similar dimensions and construction method to the Heathrow Express shaft. However, its applicability for shafts of diameter greater than $11 \mathrm{~m}$ or built using diaphragm walls, bored piles or sheet piles is questionable. For example, it was difficult to estimate reliably settlements due to excavation of the $30 \mathrm{~m}$ dia. Crossrail tunnel boring machine (TBM) launch shaft at Limmo Peninsula, which was considerably larger than the Heathrow Express shaft, as illustrated in Figure 2.

Given this uncertainty, designers of shafts in London sometimes develop bespoke variations of the New and Bowers (1994) relation to conservatively account for larger diameter shafts in similar ground conditions. On the other hand, published field observations for circular shafts, shown in Figure 1, suggest that Equation 1 might be particularly conservative for pre-installed shafts: for example, a maximum settlement of $0 \cdot 01 \% H$ was reported by Muramatsu and Abe (1996) due to excavation of a $28 \mathrm{~m}$ dia. diaphragm wall shaft in granular soil, compared with a maximum settlement of $0.06 \% \mathrm{H}$ suggested by Equation 1. Schwamb et al. (2016) also reported significantly smaller movements of less than $0.01 \% H$ during excavation of a $30 \mathrm{~m}$ dia. and $73 \mathrm{~m}$ deep diaphragm wall shaft in Lambeth Group, Thanet Sand and Chalk. Greater settlements were reported during installation of the $84 \mathrm{~m}$ deep diaphragm wall panels themselves before any shaft excavation.

\section{Overview of the circular case study shafts}

In this study, field records of recent circular shaft construction were assembled from three tunnelling projects in London

- Crossrail

- London Power Tunnels (LPT) project

- Transport for London's Northern line extension (NLE).

A description of these projects is provided in the following section and details of the 27 case study shafts are summarised in Tables 1-3. Further details of these shafts are given by Faustin (2017).

\section{$2.1 \quad$ Northern line extension (NLE)}

Transport for London commissioned an extension of the existing Northern line underground line to Battersea to regenerate
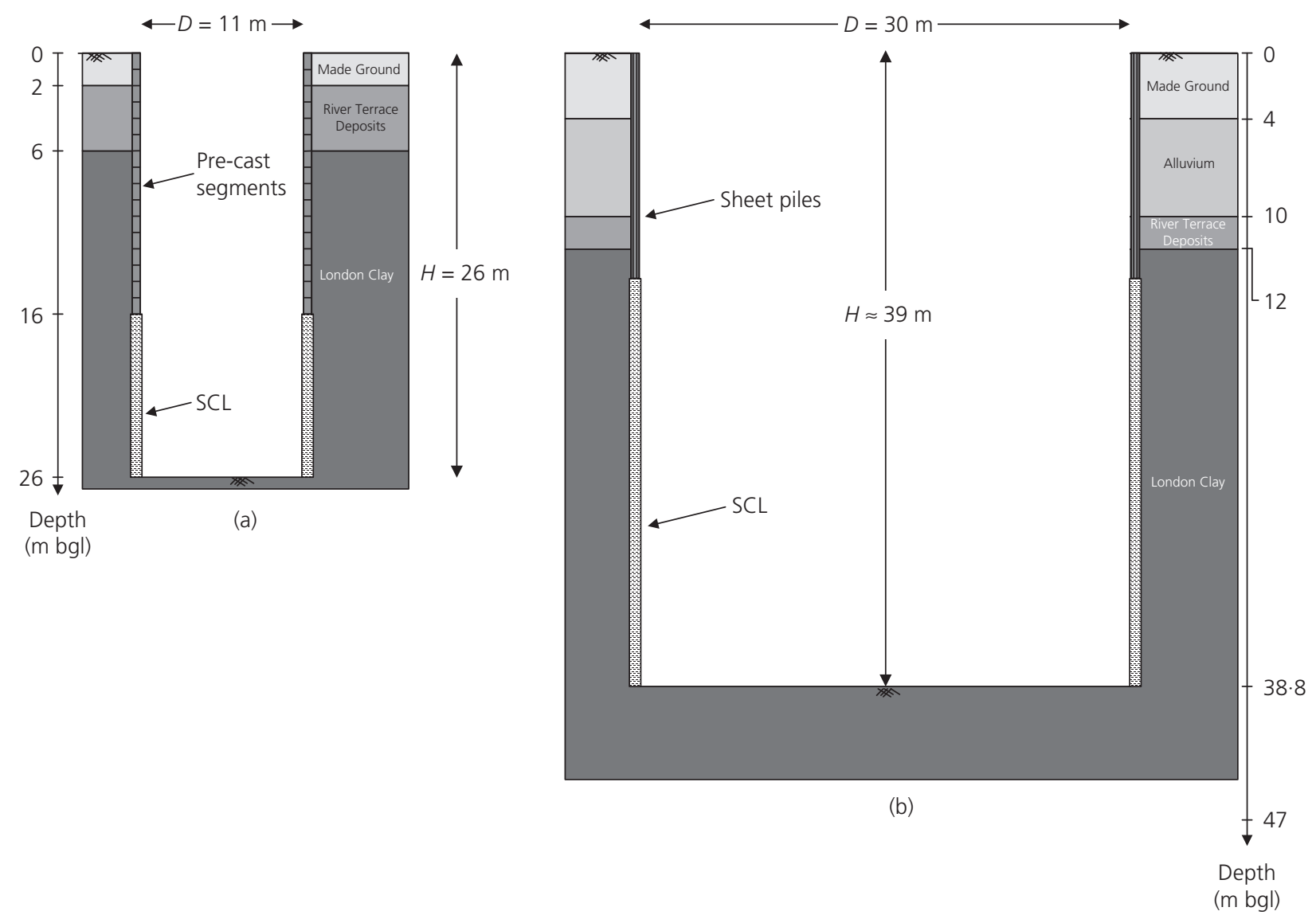

Figure 2. Comparison of (a) the $11 \mathrm{~m}$ dia. Heathrow Express trial tunnel shaft (New and Bowers, 1994) and (b) the $30 \mathrm{~m}$ dia. Crossrail TBM launch shaft at Limmo Peninsula, east London 
Table 1. Overview of the NLE case study shafts

\begin{tabular}{|c|c|c|c|c|c|}
\hline Shaft location & Construction method & $\begin{array}{c}\text { Internal } \\
\text { diameter: } \mathbf{m}\end{array}$ & $\begin{array}{l}\text { Excavation } \\
\text { depth: } m\end{array}$ & $\begin{array}{l}\text { Lining } \\
\text { thickness: } \mathrm{m}\end{array}$ & Encountered strata \\
\hline \multirow[t]{3}{*}{ Kennington Green } & Secant bored piles & 15 & $13 \cdot 6$ & $0 \cdot 6$ & Made Ground (2.2 m) \\
\hline & $\mathrm{SCL}$ & - & $12 \cdot 5(26 \cdot 1)$ & - & River Terrace Deposits ( $5.3 \mathrm{~m}$ ) \\
\hline & & - & - & - & London Clay (21 m) \\
\hline \multirow[t]{4}{*}{ Kennington Park } & Secant bored piles & 15 & $16 \cdot 1$ & 0.6 & Made Ground (2 m) \\
\hline & $\mathrm{SCL}$ & - & $10 \cdot 1(26 \cdot 2)$ & - & River Terrace Deposits $(5.8 \mathrm{~m})$ \\
\hline & & - & - & - & London Clay (18.5 m) \\
\hline & & - & - & - & Lambeth Group \\
\hline
\end{tabular}

Table 2. Overview of the LPT case study shafts

\begin{tabular}{|c|c|c|c|c|c|}
\hline Shaft location & $\begin{array}{l}\text { Construction } \\
\text { method }\end{array}$ & $\begin{array}{c}\text { Internal } \\
\text { diameter: m }\end{array}$ & $\begin{array}{l}\text { Excavation } \\
\text { depth: } m\end{array}$ & $\begin{array}{l}\text { Lining } \\
\text { thickness: } \mathrm{mm}\end{array}$ & Encountered strata \\
\hline \multirow[t]{2}{*}{ Channel Gate Road (CGR) } & Pre-cast segments & $12 \cdot 5$ & $22 \cdot 2$ & 325 & Made Ground (2.2 m) \\
\hline & $\mathrm{SCL}$ & $12 \cdot 5$ & $10 \cdot 7(32.9)$ & 312 & London Clay (75 m) \\
\hline \multirow[t]{3}{*}{ Eade Road (EDR) } & Pre-cast segments & $12 \cdot 5$ & $26 \cdot 7$ & 325 & Made Ground (1.4 m) \\
\hline & $\mathrm{SCL}$ & $13 \cdot 5$ & $12 \cdot 6(39 \cdot 3)$ & 338 & London Clay (37 m) \\
\hline & & - & - & - & Lambeth Group \\
\hline \multirow[t]{3}{*}{ Earls Court Road (ECRT) } & Pre-cast segments & $10 \cdot 5$ & $29 \cdot 9$ & 300 & Made Ground (1.9 m) \\
\hline & $\mathrm{SCL}$ & $11 \cdot 4$ & $9.6(39.5)$ & 250 & Superficial Deposits (0.8 m) \\
\hline & & - & - & - & London Clay (49.2 m) \\
\hline \multirow[t]{5}{*}{ Hackney } & Diaphragm walls & $12 \cdot 7$ & $27 \cdot 2$ & 1300 & Made Ground $(2 \cdot 2 \mathrm{~m})$ \\
\hline & & - & - & - & Superficial Deposits (3.2 m) \\
\hline & & - & - & - & Lambeth Group (6.3 m) \\
\hline & & - & - & - & Thanet Sand $(17 \mathrm{~m})$ \\
\hline & & - & - & - & Chalk \\
\hline \multirow[t]{3}{*}{ Highbury (HBY) } & Pre-cast segments & 15 & $25 \cdot 4$ & 350 & Made Ground (2.5 m) \\
\hline & $\mathrm{SCL}$ & $16 \cdot 1$ & $9 \cdot 8(35 \cdot 2)$ & 320 & London Clay (25.8 m) \\
\hline & & - & - & - & Lambeth Group \\
\hline \multirow[t]{3}{*}{ Islington (ISL) } & Pre-cast segments & $10 \cdot 5$ & $27 \cdot 7$ & 300 & Made Ground (3.2 m) \\
\hline & $\mathrm{SCL}$ & 11.4 & $9 \cdot 9(37 \cdot 6)$ & 240 & London Clay (28.3 m) \\
\hline & & - & - & - & Lambeth Group \\
\hline \multirow[t]{2}{*}{ Kensal Green no. 1 (KG1) } & Pre-cast segments & 15 & $17 \cdot 7$ & 350 & Made Ground (1.8 m) \\
\hline & $\mathrm{SCL}$ & $15 \cdot 9$ & $8 \cdot 8(26 \cdot 5)$ & 240 & London Clay (76.3 m) \\
\hline \multirow[t]{2}{*}{ Kensal Green no. 2 (KG2) } & Pre-cast segments & $12 \cdot 5$ & $30 \cdot 2$ & 350 & Made Ground (1.9 m) \\
\hline & $\mathrm{SCL}$ & $13 \cdot 4$ & $12 \cdot 5(42 \cdot 7)$ & 275 & London Clay $(76.3 \mathrm{~m})$ \\
\hline \multirow[t]{3}{*}{ St John's Wood no. 1 (SJW1) } & Pre-cast segments & $12 \cdot 5$ & $33 \cdot 1$ & 350 & Made Ground (2.9 m) \\
\hline & $\mathrm{SCL}$ & $13 \cdot 8$ & $12 \cdot 5(45 \cdot 6)$ & 315 & Superficial Deposits (1.2 m) \\
\hline & & - & - & - & London Clay (61.4 m) \\
\hline \multirow[t]{3}{*}{ St John's Wood no. 2 (SJW2) } & Pre-cast segments & $6 \cdot 0$ & $34 \cdot 5$ & 225 & Made Ground (4.6 m) \\
\hline & $\mathrm{SCL}$ & 10 & $12 \cdot 5(47)$ & 300 & Superficial Deposits (1.2 m) \\
\hline & & - & - & - & London Clay $(61.4 \mathrm{~m})$ \\
\hline \multirow[t]{3}{*}{ St Pancras (SPC) } & Pre-cast segments & $10 \cdot 5$ & $35 \cdot 7$ & 300 & Made Ground (2.0 m) \\
\hline & $\mathrm{SCL}$ & 11.4 & $9 \cdot 1(44 \cdot 8)$ & 305 & London Clay (43.6 m) \\
\hline & & - & - & - & Lambeth Group \\
\hline \multirow[t]{3}{*}{ Wandsworth (WAN) } & Jacked 'wet' caissons & 15 & $22 \cdot 7$ & 350 & Made Ground (2.5 m) \\
\hline & $\mathrm{SCL}$ & 16 & $12 \cdot 5(35 \cdot 2)$ & 285 & Superficial Deposits (4.5 m) \\
\hline & & - & - & - & London Clay (41.9 m) \\
\hline \multirow[t]{2}{*}{ Willesden (WIL) } & Pre-cast segments & $12 \cdot 5$ & $20 \cdot 3$ & 350 & Made Ground (1.7 m) \\
\hline & $\mathrm{SCL}$ & $13 \cdot 4$ & $8.7(29)$ & 225 & London Clay (74.4 m) \\
\hline \multirow[t]{3}{*}{ Wimbledon (WIM) } & Jacked 'wet' caissons & 15 & $10 \cdot 5$ & 350 & Made Ground ( $2 \cdot 3 \mathrm{~m})$ \\
\hline & Pre-cast segments & 15 & $16(26 \cdot 5)$ & 350 & Superficial Deposits (2.0 m) \\
\hline & $\mathrm{SCL}$ & 16 & $10 \cdot 7(37 \cdot 2)$ & 310 & London Clay (45.4 m) \\
\hline
\end{tabular}

part of south London. The $3 \mathrm{~km}$ extension included two permanent circular shafts at Kennington Green and Kennington Park, located approximately $300 \mathrm{~m}$ apart, as shown in Figure 3 and detailed in Table 1. These shafts were built between April and August 2016 to facilitate the main tunnelling works. In the long term they will provide ventilation, cooling and emergency access to the new tunnel extension. 
Table 3. Overview of the Crossrail case study shafts

\begin{tabular}{|c|c|c|c|c|c|}
\hline Shaft location & Construction method & $\begin{array}{c}\text { Internal } \\
\text { diameter: } \mathrm{m}\end{array}$ & $\begin{array}{l}\text { Excavation } \\
\text { depth: } m\end{array}$ & $\begin{array}{l}\text { Lining thickness: } \\
\text { mm }\end{array}$ & Encountered strata \\
\hline \multirow{4}{*}{$\begin{array}{l}\text { Farringdon Western } \\
\text { ticket hall }\end{array}$} & \multirow[t]{4}{*}{ Secant bored piles } & 15 & $24 \cdot 7$ & 1200 & Made Ground (3 m) \\
\hline & & - & - & - & London Clay (6 m) \\
\hline & & - & - & - & Lambeth Group (17 m) \\
\hline & & - & - & - & Thanet Sand \\
\hline \multirow[t]{3}{*}{ Farringdon Hayne St } & $\begin{array}{l}\text { Jacked pre-cast } \\
\text { segments }\end{array}$ & 5 & $14 \cdot 6$ & 200 & Made Ground (1 m) \\
\hline & \multirow[t]{2}{*}{$\mathrm{SCL}$} & $6 \cdot 2$ & $10 \cdot 9(25 \cdot 5)$ & 300 & London Clay (22 m) \\
\hline & & - & - & - & Lambeth Group \\
\hline \multirow[t]{4}{*}{ Fisher Street main shaft } & Secant bored piles & 15 & $11 \cdot 85$ & 620 & Made Ground (3 m) \\
\hline & \multirow[t]{3}{*}{$\mathrm{SCL}$} & - & $\begin{array}{l}19 \cdot 13 \\
(30 \cdot 98)\end{array}$ & - & Superficial Deposits (4 m) \\
\hline & & - & - & - & London Clay (17.5 m) \\
\hline & & - & - & - & Lambeth Group \\
\hline \multirow[t]{4}{*}{ Fisher Street grout shaft } & \multirow[t]{4}{*}{ Pre-cast segments } & 5 & $9 \cdot 0$ & 300 & Made Ground (4.5 m) \\
\hline & & - & - & - & River Terrace Deposits $(3.3 \mathrm{~m})$ \\
\hline & & - & - & - & London Clay $(18.5 \mathrm{~m})$ \\
\hline & & - & - & - & Lambeth Group \\
\hline \multirow[t]{4}{*}{ Limmo Peninsula main shaft } & \multirow[t]{4}{*}{ Diaphragm wall } & 30 & 44 & 1200 & Superficial Deposits (17 m) \\
\hline & & - & - & - & London Clay (31 m) \\
\hline & & - & - & - & Lambeth Group (18 m) \\
\hline & & - & - & - & Thanet Sand \\
\hline \multirow{5}{*}{$\begin{array}{l}\text { Limmo Peninsula } \\
\text { auxiliary shaft }\end{array}$} & Steel sheet piles & 28 & 14 & 450 & Superficial Deposits (16.7 m) \\
\hline & \multirow[t]{4}{*}{$\mathrm{SCL}$} & - & $25(39)$ & 800 & London Clay $(75 \mathrm{~m})$ \\
\hline & & - & - & - & Lambeth Group (6.3 m) \\
\hline & & - & - & - & Thanet Sand $(17 \mathrm{~m})$ \\
\hline & & - & - & - & Chalk \\
\hline \multirow{4}{*}{$\begin{array}{l}\text { Whitechapel Cambridge } \\
\text { Heath }\end{array}$} & \multirow[t]{4}{*}{ Diaphragm wall } & $28 \cdot 2$ & 32 & 1500 & Made Ground (4.5 m) \\
\hline & & - & - & - & Superficial Deposits (3 m) \\
\hline & & - & - & - & London Clay $(25.5 \mathrm{~m})$ \\
\hline & & - & - & - & Lambeth Group \\
\hline \multirow[t]{3}{*}{ Whitechapel no. 2} & $\begin{array}{l}\text { Jacked pre-cast } \\
\text { segments }\end{array}$ & $12 \cdot 5$ & $10 \cdot 6$ & 325 & Made Ground (8.5 m) \\
\hline & \multirow[t]{2}{*}{$\mathrm{SCL}$} & - & $18(28 \cdot 6)$ & 800 & London Clay (24.5 m) \\
\hline & & - & - & - & Lambeth Group \\
\hline Soho Sq. Southeast & $\begin{array}{l}\text { Jacked pre-cast } \\
\text { segments }\end{array}$ & $5 \cdot 0$ & 15 & Not & Made Ground (2 m) \\
\hline Soho Sq. West & $\begin{array}{l}\text { Jacked pre-cast } \\
\text { segments }\end{array}$ & $5 \cdot 0$ & 14 & Reported & Superficial Deposits (3 m) \\
\hline \multirow[t]{2}{*}{ Sheraton } & Jacked pre-cast & $5 \cdot 0$ & 14 & - & London Clay \\
\hline & segments & - & - & - & Lambeth Group \\
\hline
\end{tabular}

\subsection{LPT project}

The LPT project was commissioned by National Grid Plc to upgrade electricity cables located just below the road surface in London. New high-voltage electricity cables were routed in $32 \mathrm{~km}$ of new tunnels (3-4 m in diameter) at depths of up to $60 \mathrm{~m}$. Between March 2011 and July 2013, 14 deep circular shafts were built across London to launch the TBMs, as shown in Figure 4 and detailed in Table 2. The shafts provided access to the new tunnels, facilitated removal of spoil from the tunnel horizon and provided ventilation.

\subsection{Crossrail}

Crossrail is delivering the Elizabeth line, a new east-west railway in the UK. Figure 5 shows a plan view of the route, which connects London with Reading and Heathrow in the west and Shenfield and Abbey Wood in the east.
The railway is currently Europe's largest infrastructure project and, when fully complete in 2019 , is expected to carry 200 million people each year between London and the South East.

The $21 \mathrm{~km}$ twin-tunnelled section of the new railway crosses beneath London at depths of up to $40 \mathrm{~m}$ below ground level (bgl) in order to avoid existing underground lines, sewers, utility tunnels, building foundations and other underground infrastructure. To facilitate the new Crossrail tunnels, several large circular shafts were constructed across London. The shafts serve a variety of uses including access for equipment and personnel to the tunnel horizon, removal of spoil and ventilation. A number of relatively smaller $5 \mathrm{~m}$ dia. shafts were also built to enable compensation grouting works. In the long term, some of the shafts will be backfilled and others will be 


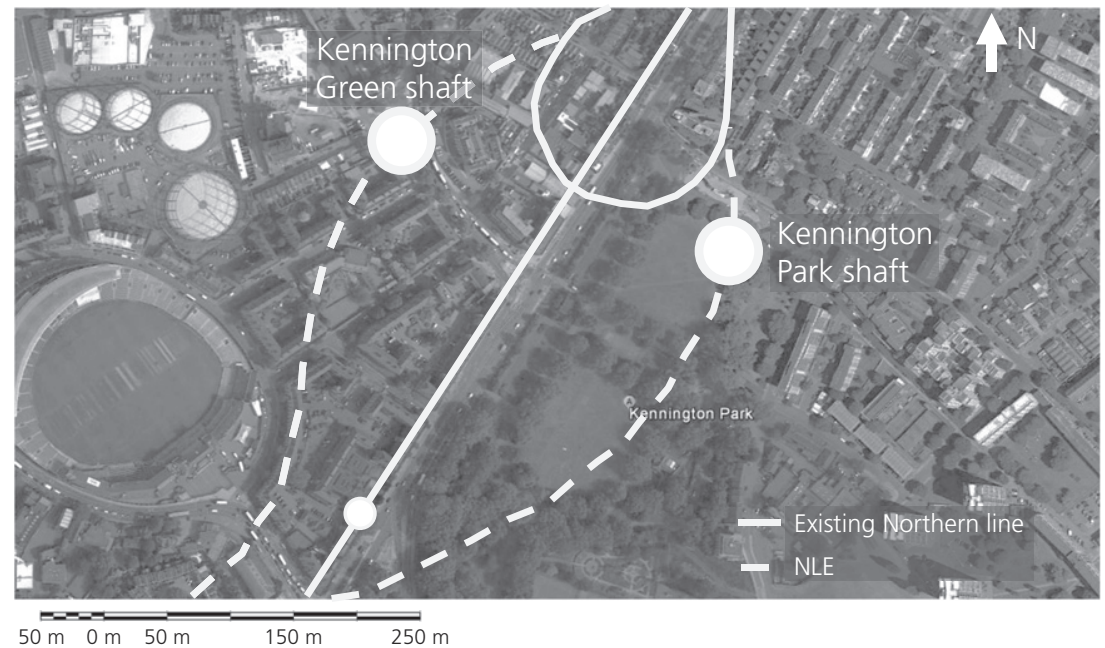

Figure 3. Location plan of the NLE shafts. Base map source: (c Google Earth (GE, 2017)

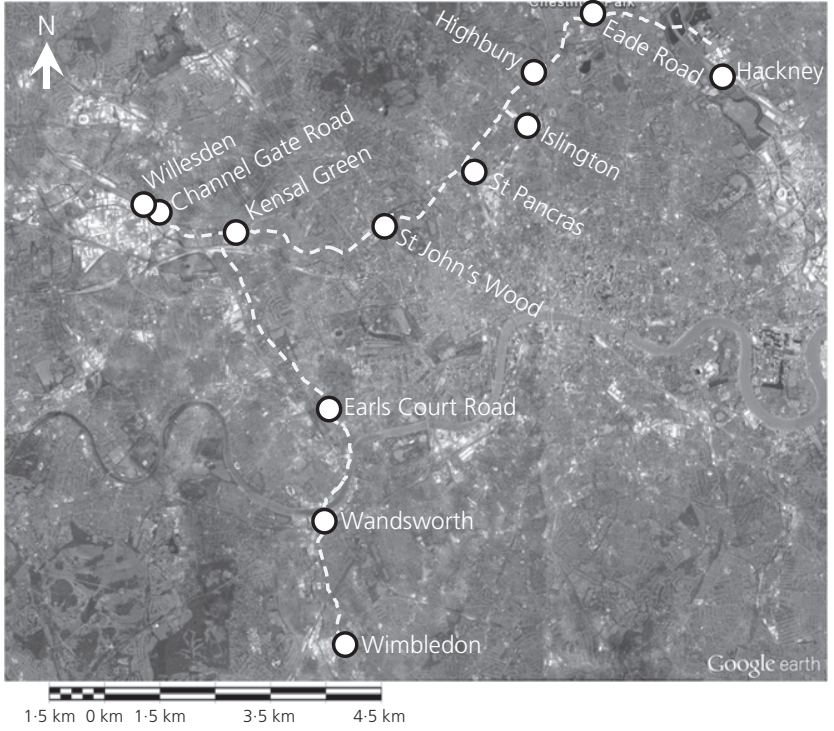

Figure 4. Location plan of the LPT shafts. Base map source: (C) Google Earth (GE, 2015)

used to provide ventilation or emergency access and exit to the completed tunnels. Field observations for seven access and ventilation shafts and four compensation grout shafts are presented in this paper, details of which shafts are given in Table 3.

\section{Typical ground conditions}

The case study shaft locations were limited to London where the ground conditions were typical of the London Basin strata, which generally comprise varying thicknesses of Superficial Deposits (Made Ground, Langley Silt, Alluvium and River Terrace Deposits) overlying stiff relatively homogeneous
London Clay of very low permeability. These strata are underlain by the Lambeth Group, Thanet Sand and Chalk. A thin layer of Harwich Formation, typically less than $1.5 \mathrm{~m}$ thick, was encountered below the London Clay at some shaft sites. For the purposes of this paper, the Harwich Formation was grouped together with the London Clay.

Most of the case study shafts were founded in London Clay while a few extended further to the Lambeth Group and Thanet Sand Formation. The stratigraphy at individual shaft sites is summarised in Tables $1-3$.

\section{Typical groundwater conditions}

There are two main aquifers in the London Basin, a shallow aquifer within the Superficial Deposits and a deep aquifer that spans the Upnor Formation of the Lambeth Group, Thanet Sand and Chalk.

\subsection{Dewatering}

Dewatering was carried out when the base of the case study shaft, or the invert of the tunnels that extend from the shaft, was located very close to or in the underlying permeable units of the Lambeth Group or Thanet Sand. Faustin et al. (2017) describe the dewatering operations carried out at Limmo Peninsula in east London to facilitate the construction of two deep circular shafts to launch the Crossrail TBMs. Passive groundwater control measures comprising sumps or depressurisation wells within the shaft were sometimes employed for case study shafts that were constructed mainly in London Clay.

With the exception of the deep shaft excavations that extended into or close to underlying permeable strata, there was apparently little drainage of groundwater associated with the 


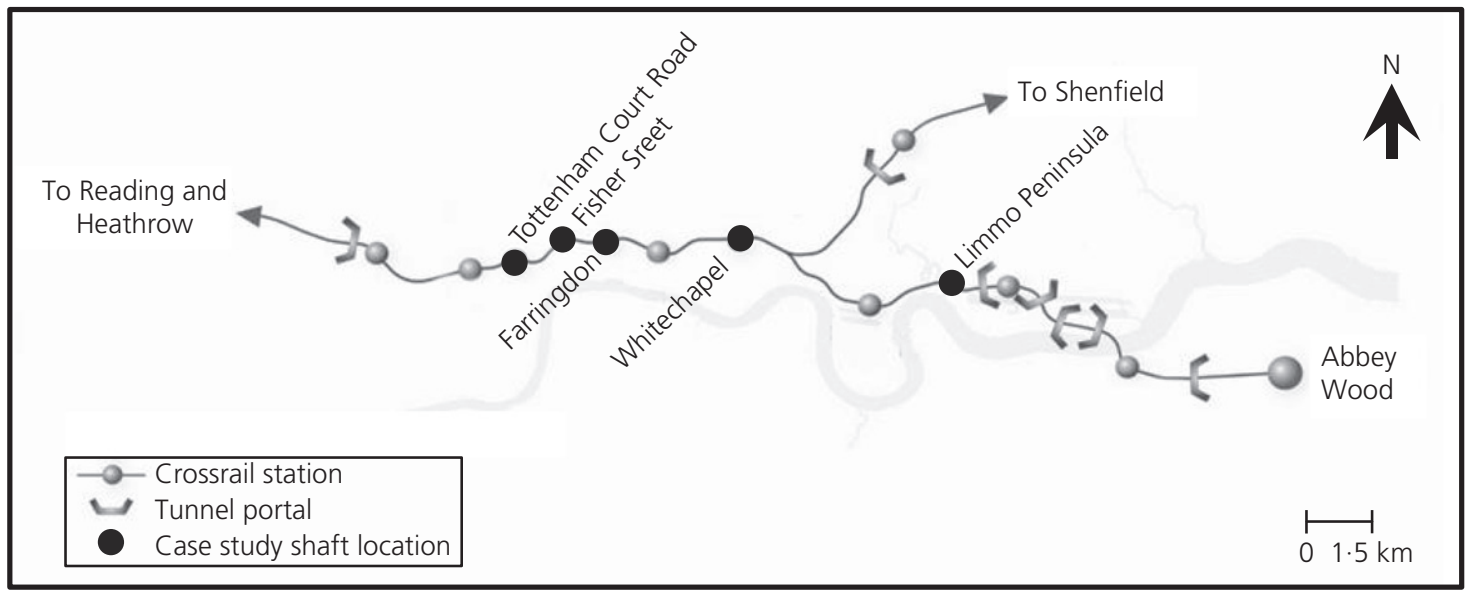

Figure 5. Plan view of Crossrail's $21 \mathrm{~km}$ twin-bore running tunnels in central London showing the case study shaft locations (basemap reproduced with kind permission from Crossrail Limited)

construction of the case study shafts and hence settlement due to groundwater lowering outside of the excavation is likely to be very small.

\section{Shaft construction categories}

The case study shafts can be classified into different categories of shaft construction: support before excavation (SBE), excavation before support (EBS) or a combination of the two (SBE and EBS).

It is common practice to describe circular shafts using terminologies such as 'segmental shafts', 'caisson shafts' or 'segmentally lined shafts'. However, these descriptions do not indicate whether the segments are jacked-in the ground or installed using a concurrent excavation and installation sequence. This differentiation is important as the mode of shaft construction greatly influences ground movements around the shaft during excavation.

\subsection{SBE (pre-installed shaft linings)}

For the SBE shaft construction category, the soil is supported by a pre-installed shaft lining before excavation of the soil between the pre-installed shaft lining is carried out. SBE shaft construction for the case study shafts involved pre-installed diaphragm walls, bored piles and steel sheet piles. This type of shaft construction is generally adopted in ground that is not stable or competent or where groundwater ingress is a concern. The support provided to the ground prevents large reductions of in situ horizontal soil stresses and stiffness during excavation.

Figure 6 shows the SBE shaft construction adopted for Crossrail's $44 \mathrm{~m}$ deep main shaft at Limmo Peninsula. The pre-installed shaft lining comprised $53 \mathrm{~m}$ long and $1.2 \mathrm{~m}$ thick diaphragm wall panels.
Three smaller $5 \mathrm{~m}$ dia. case study shafts were built using jacked pre-cast segments to enable compensation grout works for Crossrail. This type of shaft construction is included in the SBE shaft construction category because the pre-cast segments provide support to the soil before it is excavated. The only exception would be if the excavation is carried out ahead of the lead cutting ring to aid the jacking-in process, as shown in Figure 7. In such instances, there would be some in situ horizontal stress relief of the ground during excavation, which can cause additional ground movement. It is difficult to quantify the effect of any unloading due to excavation ahead of the lead cutting ring because it is done on an ad hoc basis depending on the site conditions and is often not formally reported. For this reason, settlements observed around jacked pre-cast shafts are presented separately in this paper.

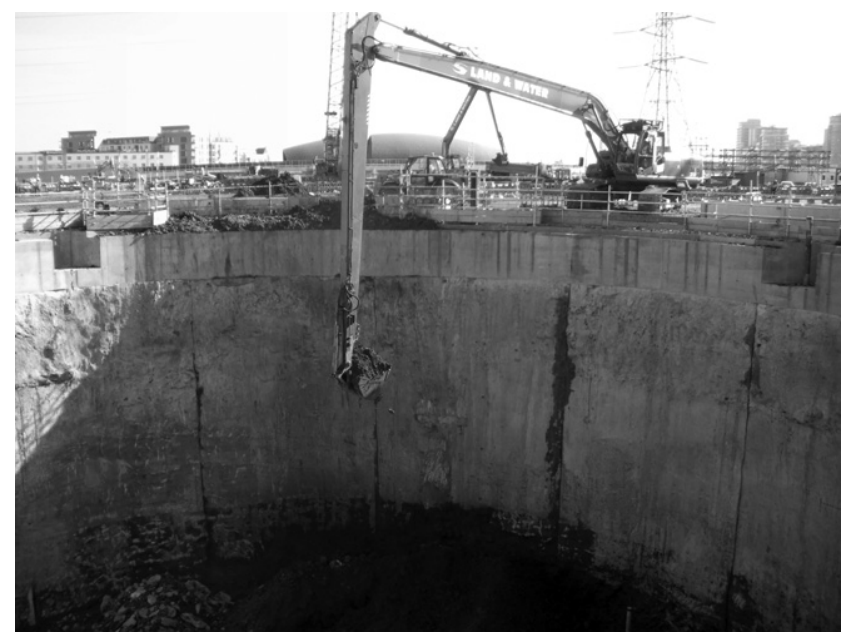

Figure 6. Excavation in front of $1.2 \mathrm{~m}$ thick pre-installed diaphragm walls for Crossrail's $30 \mathrm{~m}$ dia. and $44 \mathrm{~m}$ deep TBM launch shaft at Limmo Peninsula (SBE construction) 
Geotechnical Engineering

Volume 171 Issue GE5
Case studies of circular shaft construction

in London

Faustin, Elshafie and Mair

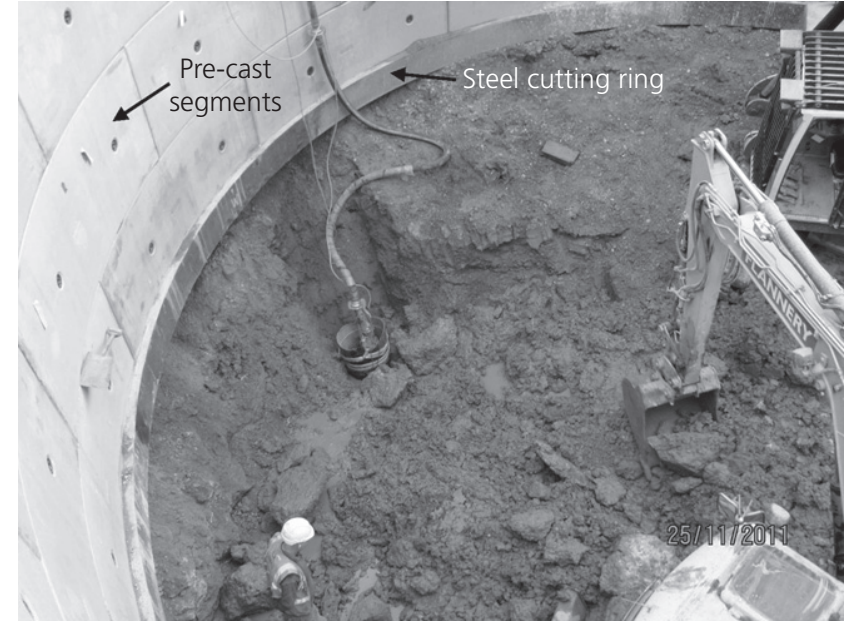

Figure 7. Jacked pre-cast segments for Crossrail's construction access shaft at Whitechapel: excavation ahead of the lead cutting ring, which may cause a reduction of in situ horizontal soil stress and stiffness

It is also worth mentioning that deep excavation supports like diaphragm walls provide much greater restraint to 'base heave' type mechanisms that could promote ground movement compared with a jacked segment form of construction. However, base heave movements were not an issue for the jacked pre-cast segment case study shafts because the factor of safety against base heave movements was quite high.

\subsection{EBS (concurrent shaft linings)}

The EBS shaft construction is comparable to tunnel excavations ahead of the tunnel lining; the ground is progressively excavated in sections, typically $1.0 \mathrm{~m}$ to $1.2 \mathrm{~m}$ in height, and the support (i.e. the shaft lining) is constructed after the ground has been exposed. When a ring is complete, the process is repeated for the underlying ring, as shown in Figure 8. The EBS shaft construction is employed in stable ground where groundwater ingress is not a concern. Like tunnels, the concurrent shaft lining used for the EBS shaft construction category is either pre-cast segments or a SCL.

In London, where there is sometimes a relatively small thickness of Superficial Deposits overlying London Clay, the top section of the shaft may be supported by pre-cast segments and the bottom section of the shaft, located in London Clay, may be supported by a SCL. A typical EBS circular shaft construction involving pre-cast segments in the top section and sprayed concrete in the bottom section is shown in Figure 9. This type of shaft construction was adopted in 11 of the case study shafts.

It is important to differentiate between pre-cast segments that are installed concurrently (EBS shaft construction) and precast segments that are jacked into the ground (SBE shaft

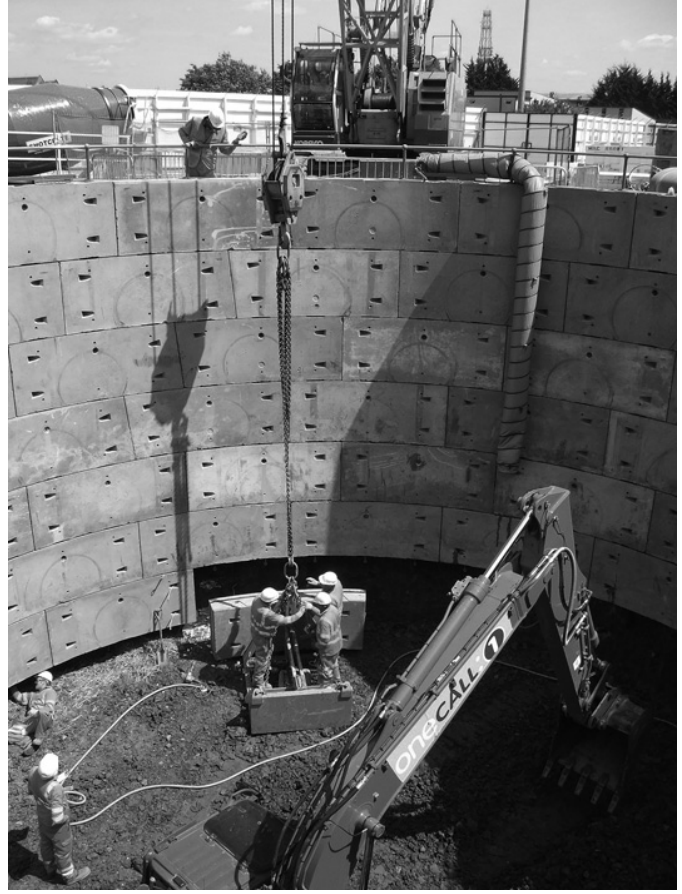

Figure 8. Erection of pre-cast segments for National Grid's LPT project (NG, 2015). The ground is exposed prior to erecting the shaft lining (EBS construction)

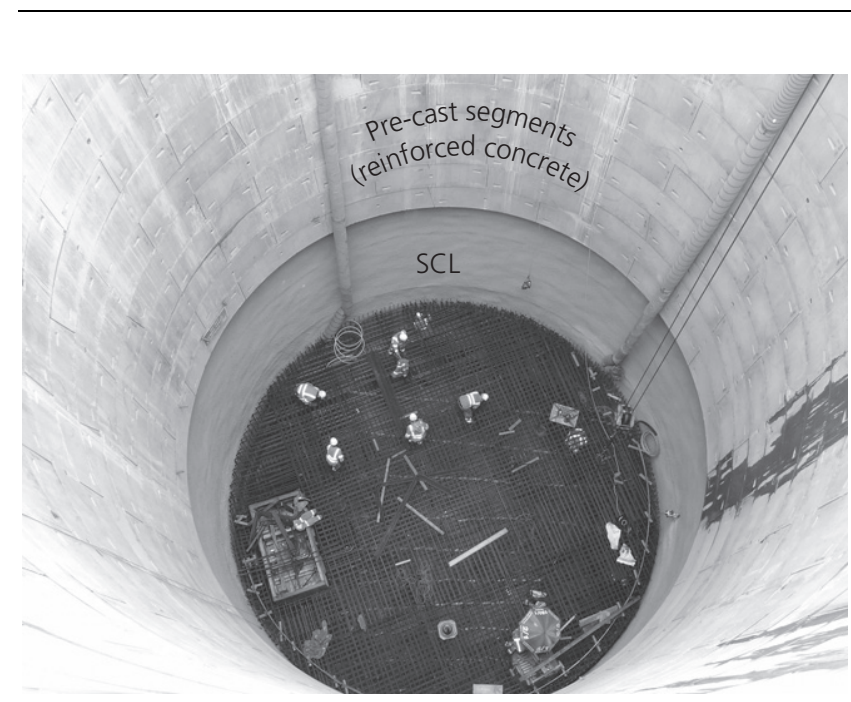

Figure 9. EBS shaft construction for National Grid's LPT project (NG, 2015)

construction). In this paper, the latter are called jacked pre-cast segments.

\subsection{Combined SBE and EBS shaft construction (dual-lined shafts)}

Eight of the case study shafts were supported by two forms of shaft linings: a pre-installed shaft lining in the top section to support the Superficial Deposits (SBE shaft construction) and 


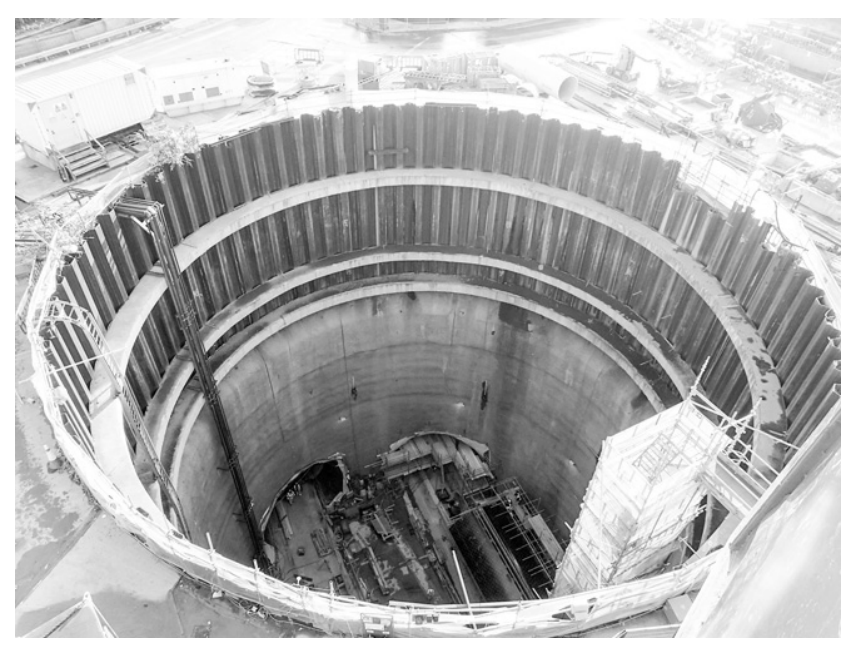

Figure 10. A $28 \mathrm{~m}$ dia. and $39 \mathrm{~m}$ deep TBM launch shaft at Limmo Peninsula comprising pre-installed sheet piles (SBE construction) and a SCL (EBS construction)

SCL in the bottom section through the stiff, homogeneous and relatively impermeable London Clay (EBS shaft construction).

Crossrail's auxiliary TBM launch shaft at Limmo Peninsula in east London is an example of a dual-lined shaft involving steel sheet piles and a SCL (Figure 10). The $14 \mathrm{~m}$ long steel sheet piles were embedded approximately $1 \mathrm{~m}$ into the London Clay before the upper part of the shaft was excavated. The shaft construction method then changed to EBS construction involving a SCL: the more stable London Clay was excavated in sections and each section was supported with sprayed concrete before excavating the next section. When a complete SCL ring was formed, the process was repeated for the underlying rings to a final shaft excavation depth of $39 \mathrm{~m} \mathrm{bgl}$.

\section{Settlement during installation of pre-installed shaft linings}

Ground movements may arise due to the installation of a preinstalled shaft lining (and during subsequent excavation between the pre-installed shaft linings). Neglecting the jacked pre-cast compensation grout shafts, the pre-installed case study shaft walls comprised diaphragm walls, bored piles and steel sheet piles. Under controlled measures, bentonite slurry provides stability to an excavated diaphragm wall panel. However, the construction process inherently reduces the horizontal stress in the ground and causes movement of the adjacent ground. Secant bored piles are commonly cased through the Superficial Deposits overlying London Clay using temporary or permanent steel casings. The process of driving steel casings or sheet piles into the ground can be expected to generate some ground movement.

Figure 11 shows the settlements observed during the installation of pre-installed shaft linings at Cambridge Heath,
Farringdon and Kennington Green. Approximately $6 \mathrm{~mm}$ of settlement, equivalent to $0.02 \%$ of the wall excavation depth $(0.02 \% H)$, occurred during the installation of $1.5 \mathrm{~m}$ thick diaphragm wall panels for the circular case study shaft at Cambridge Heath (Figures 11(a) and 11(b)).

Figure 11(d) shows relatively large movements, in the region of $+3 \mathrm{~mm}$ to $-5 \mathrm{~mm}$, at approximately $30 \mathrm{~m}$ from the Farringdon shaft. These movements are likely to have arisen from other site activities rather than installation of the piled shaft lining. Neglecting these measurements, very small displacements $(2-3 \mathrm{~mm})$ were observed during installation of the $14 \mathrm{~m}$ and $33 \mathrm{~m}$ deep secant bored piles at Farringdon and Kennington Green, respectively. These movements equate to a settlement of approximately $0 \cdot 01 \% H$.

In comparison, Clough and O'Rourke (1990) reported a greater maximum settlement of approximately $0 \cdot 04 \% \mathrm{H}$ due to the installation of diaphragm wall panels in stiff to very hard clay.

\section{Settlement during shaft excavation}

This section presents field observations of ground surface settlements adjacent to circular shafts during excavation for

- SBE shaft construction (pre-installed shaft linings)

- EBS shaft construction (concurrent shaft linings)

- combined SBE and EBS shaft construction (dual shaft linings)

The data were assembled into charts of settlement normalised by the shaft excavation depth $\left(S_{\mathrm{v}} / H\right)$ against distance from the shaft normalised by the shaft excavation depth $(x / H)$. The measurements do not include any contribution from dewatering activities and any settlement due to drainage towards the excavation was considered negligible given the ground conditions.

\subsection{SBE shaft construction}

A maximum settlement of $0.03 \% H$ was observed during excavation of the SBE case study shafts at Hackney, Farringdon, Cambridge Heath and Limmo Peninsula, as shown in Figure 12. The Limmo Peninsula main shaft was supported by diaphragm walls while the other three shafts were supported by secant bored piles. Settlements around the Limmo Peninsula main shaft, presented in Figure 12, are for an excavation depth of $39 \mathrm{~m}$ rather than the final shaft excavation depth of $44 \mathrm{~m}$. For comparison, Clough and O'Rourke (1990) reported a much greater maximum settlement of $0 \cdot 3 \% \mathrm{H}$ behind braced or tied-back retaining walls in stiff clays, residual soils and sands. Circular pre-installed shaft linings are stiffer than a conventional plane strain wall and generate smaller settlements of the surrounding ground due to hoop compression of the circular shaft lining during excavation. 


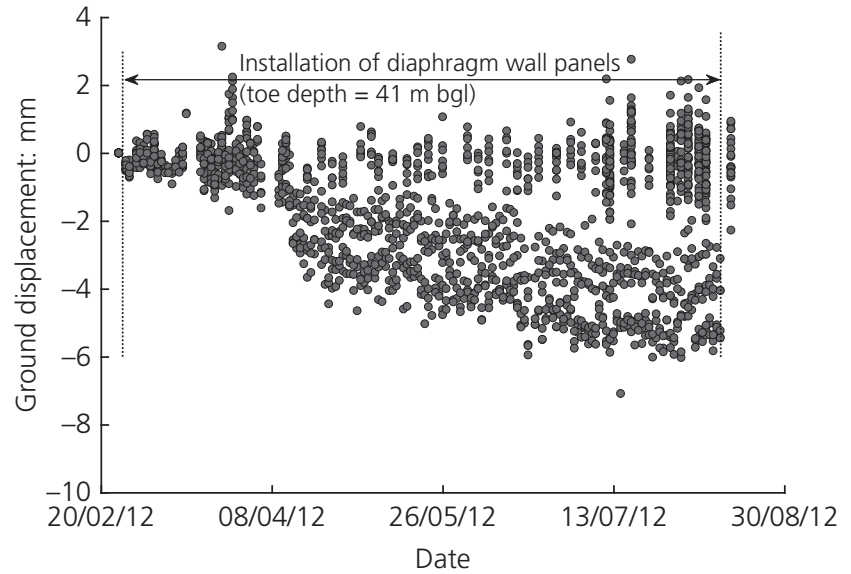

(a)

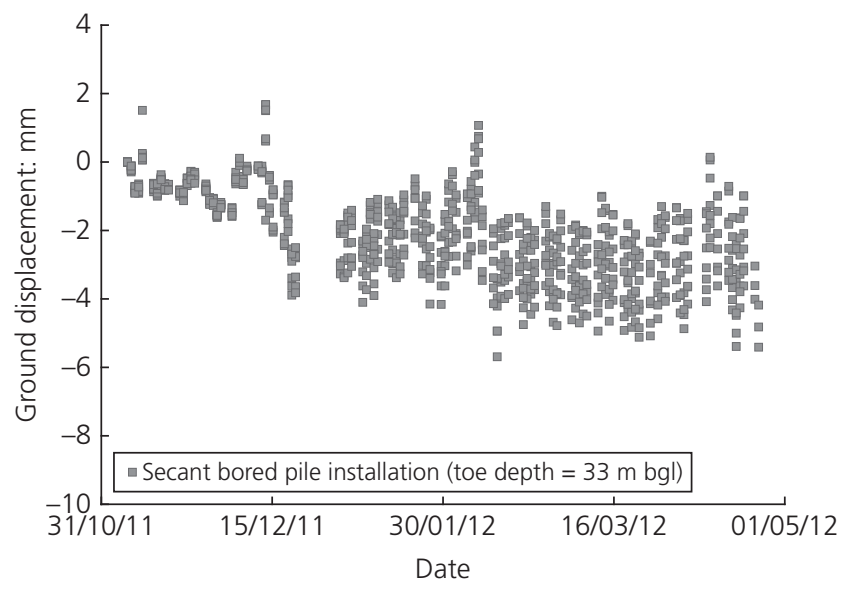

(c)

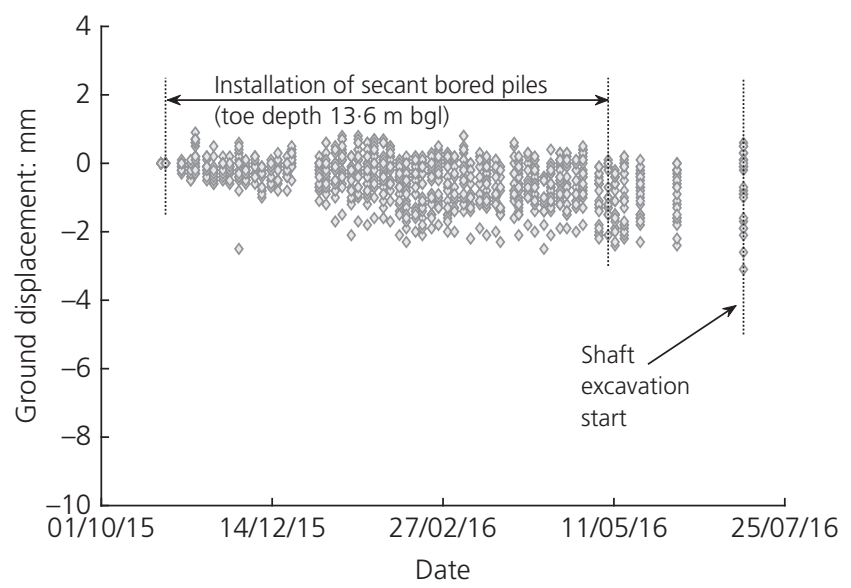

(e)

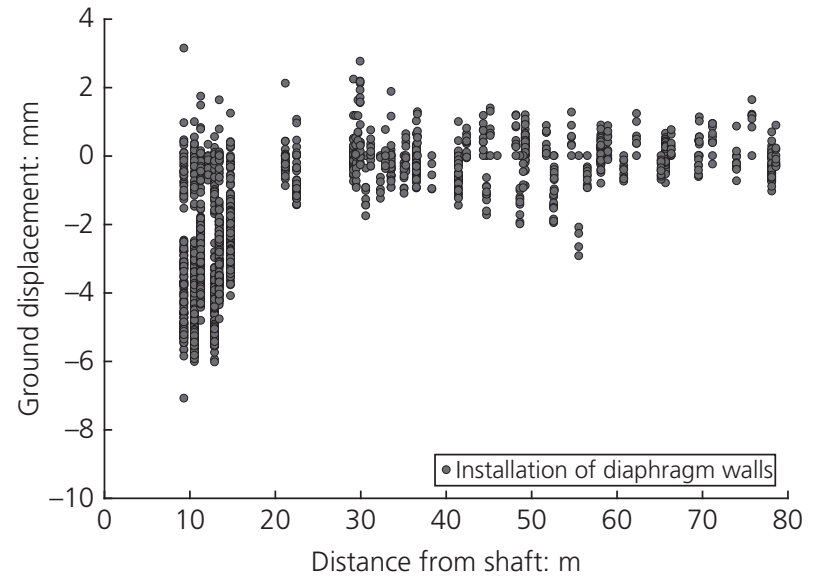

(b)

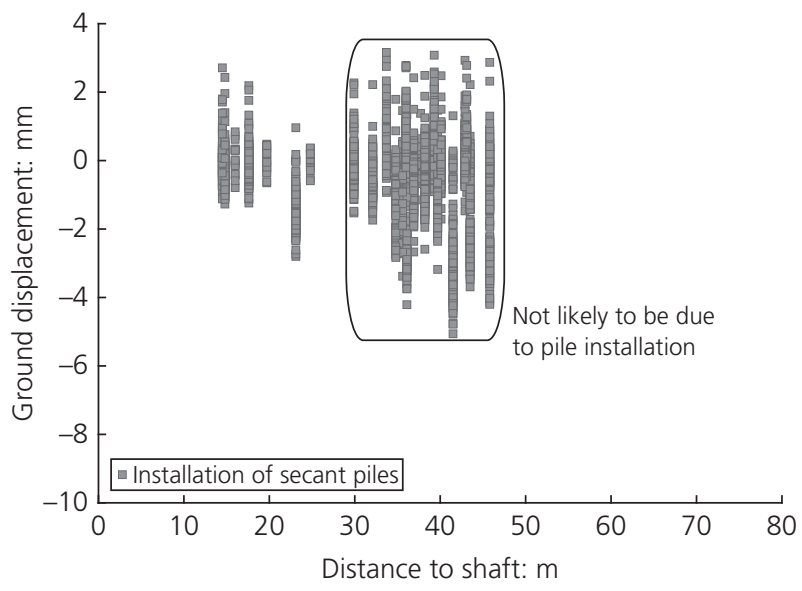

(d)

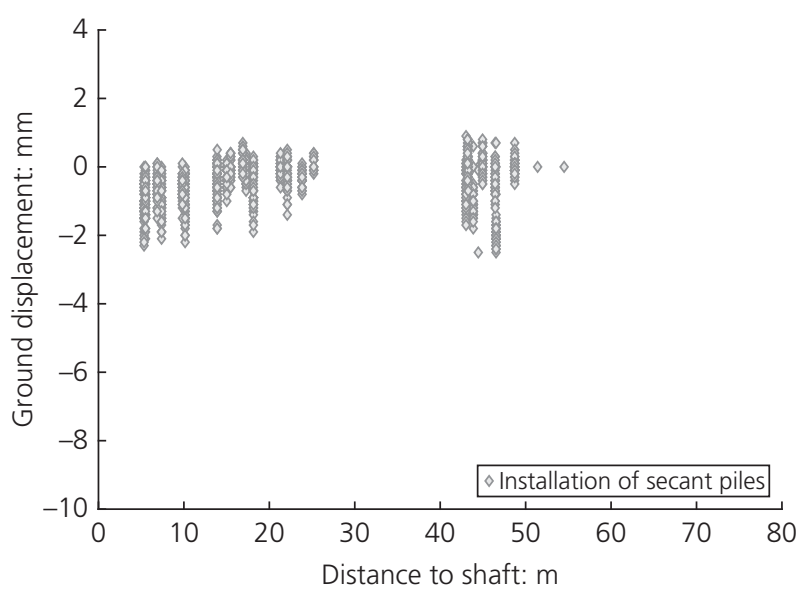

(f)

Figure 11. Settlements arising from installation of pre-installed shaft linings in London: (a) and (b) Cambridge Heath; (c) and (d) Farringdon; (e) and (f) Kennington Green

More importantly, the maximum observed settlements during SBE shaft excavation were considerably smaller than the value of $0.06 \% H$ reported by New and Bowers (1994) for an EBS shaft construction. The maximum total settlements at the
Farringdon and Cambridge Heath shafts due to installation of the pre-installed walls and subsequent excavation of the shafts were $0 \cdot 02 \% H$ and $0 \cdot 04 \% H$, respectively. These field observations confirm that Equation 1, which is based on EBS shaft 


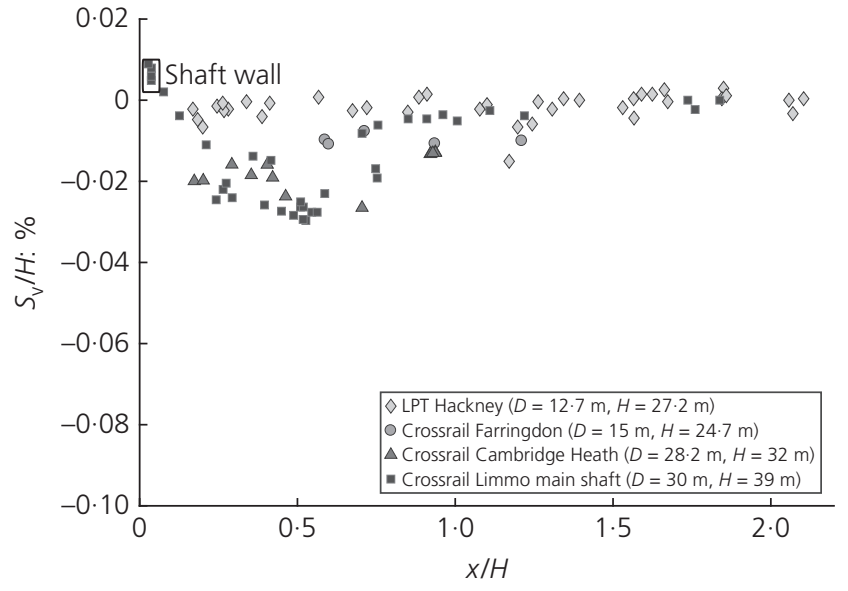

Figure 12. Field observations of settlements around pre-installed circular shafts (SBE shaft construction)

construction, is overly conservative when applied to SBE shaft construction, in which the soil is supported by a pre-installed wall before the shaft is excavated, provided the quality of workmanship is high.

Negligible settlement was observed at a distance of approximately $1.0 \mathrm{H}$ to $1.5 \mathrm{H}$ from the pre-installed shaft lining and the influence of shaft diameter on the magnitude of settlement is evident. The smallest settlements were observed during excavation of the $12.7 \mathrm{~m}$ dia. diaphragm wall shaft at Hackney $(0 \cdot 005 \% H)$ and the greatest settlements were observed during excavation of the $28 \mathrm{~m}$ dia. Cambridge Heath shaft and the $30 \mathrm{~m}$ dia. diaphragm wall shaft at Limmo Peninsula (approximately $0 \cdot 03 \% H$ ). The settlements observed during excavation of the $15 \mathrm{~m}$ dia. secant bored pile shaft at Farringdon lie in the middle of the dataset.

\subsubsection{Jacked segments}

As mentioned earlier, jacked shaft construction may cause additional ground movement if excavation is undertaken ahead of the lead cutting ring. Therefore, field observations for three $5 \mathrm{~m}$ dia. jacked shafts, involving pre-cast segments, built to enable compensation grout work for Crossrail, are presented separately.

In keeping with the trend for SBE shaft construction shown in Figure 12, smaller settlements could reasonably be expected during excavation of these $5 \mathrm{~m}$ dia. compensation grout shafts. However, the settlements observed adjacent to relatively small jacked pre-cast segments were slightly greater than those typically observed for a much larger $30 \mathrm{~m}$ dia. diaphragm wall shaft, as shown in Figure $13(0.035 \% H$ compared with $0 \cdot 030 \% H$ ). This may possibly be due to mechanical excavation ahead of the cutting ring but details of this were not reported (see Figure 7). Negligible movement was observed at a distance of approximately $1.0 \mathrm{H}$ from the jacked shaft lining.

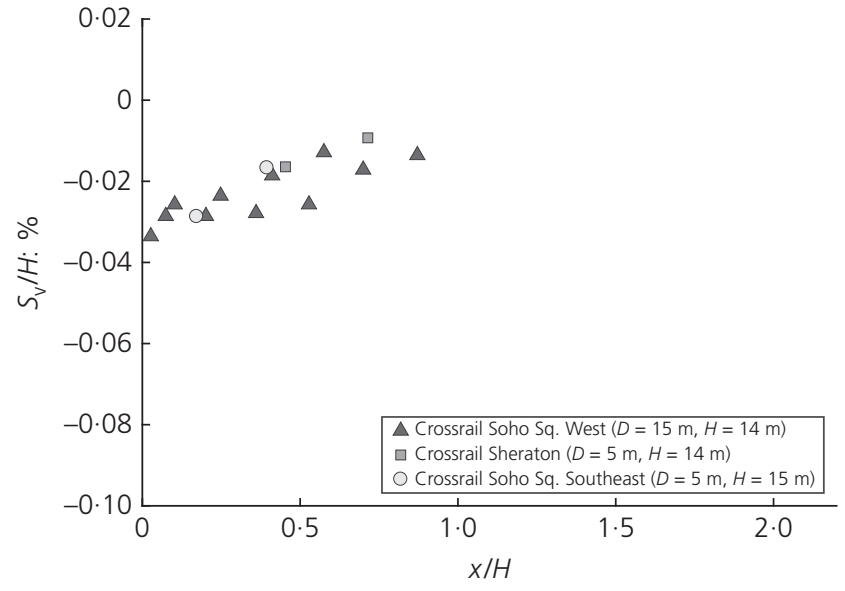

Figure 13. Field observations of settlements around jacked pre-cast segments (SBE shaft construction)

\subsection{EBS shaft construction}

Of the case study shafts considered, 11 were supported by a concurrent shaft lining involving pre-cast segments and a SCL (i.e. EBS shaft construction). Field observations of settlement during excavation are presented in Figure 14. Generally, there was a small increase in shaft diameter when the shaft lining changed from pre-cast segments to SCL, as detailed in Tables 1-3. The shaft diameters shown in Figure 14 are the internal diameters of the top segment.

The field observations showed a maximum settlement of $0 \cdot 06 \% H$ due to EBS shaft construction and negligible movement beyond a distance of $1.5 \mathrm{H}$ from the shaft. Some influence of the shaft size is evident: the smallest settlements were observed during excavation of the $6 \mathrm{~m}$ dia. shaft at St John's Wood (SJW2) while relatively greater settlements were observed

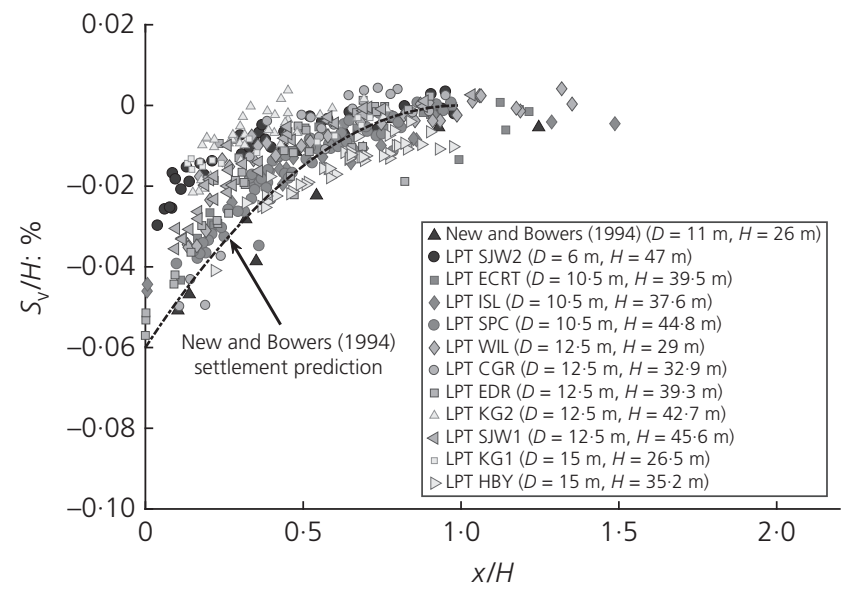

Figure 14. Field observations of settlements around concurrent shaft linings involving pre-cast segments and SCL (EBS shaft construction) 
during excavation of the larger $15 \mathrm{~m}$ dia. shaft at Highbury (HBY). There was little discernible trend in settlements around the $10 \mathrm{~m}$ and $12.5 \mathrm{~m}$ dia. shafts.

Observations during excavation of two shafts at Kensal Green (KG1 and KG2) appear anomalous: relatively small settlements were observed. It is understood that excavation of these two shafts progressed slowly due to the presence of contaminated ground. Smaller reductions in in situ horizontal soil stress and stiffness are likely if the depth of the excavated sections is smaller than the $1.0 \mathrm{~m}$ typically used for EBS shaft construction. This may have resulted in smaller settlements. However, detailed field records are not available to verify the construction sequence.

Field data and the settlement prediction reported by New and Bowers (1994) for an $11 \mathrm{~m}$ dia. shaft constructed using similar techniques (pre-cast segments followed by SCL construction) are also shown in Figure 14. The New and Bowers (1994) relationship (Equation 1) was found to provide a reasonably good estimate of the maximum settlement around concurrent shaft linings (EBS shaft construction). However, some very small settlement extended to a distance of approximately $1.5 \mathrm{H}$ from the shaft lining rather than $1.0 H$ as implied by Equation 1.

\subsection{Combined SBE and EBS shaft construction}

Eight of the case study shafts were supported by two forms of shaft linings: a pre-installed shaft lining in the top section (SBE shaft construction) and a SCL in the bottom section (EBS shaft construction). For four of these shafts, the preinstalled wall comprised jacked pre-cast segments. Therefore, settlements for these four shafts are interpreted separately.

Figure 15 shows the settlements observed around four shafts that were built using a combination of pre-installed walls (not including jacked pre-cast segments) and a concurrent shaft lining. Steel sheet piles supported the top $14 \mathrm{~m}$ of the Limmo Peninsula auxiliary shaft and secant bored piles supported the top section of the Fisher Street, Kennington Green and Kennington Park shafts. The bottom section of all four shafts was supported by a SCL. The normalised settlements generally lay in a uniform band that extended to a distance of approximately $1 \cdot 5 H$ from the shaft lining. Settlements observed during excavation of the $28 \mathrm{~m}$ dia. Limmo Peninsula auxiliary shaft were twice as great as those observed during excavation of the three smaller $15 \mathrm{~m}$ dia. shafts $(0.082 \% H$ compared with approximately $0 \cdot 040 \% H$ ).

Normalised settlements observed during excavation of duallined shafts supported by jacked pre-cast segments and sprayed concrete are shown in Figure 16. Generally, a maximum settlement of $0.06 \% \mathrm{H}$ was observed close to the shaft wall and the settlement decreased with increasing distance from the shaft.

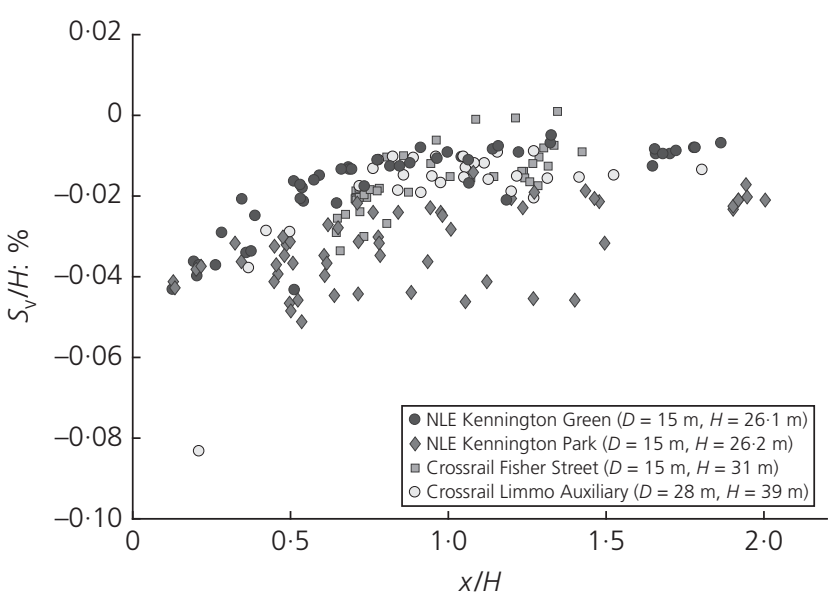

Figure 15. Field observations of settlements during excavation of dual-lined shafts involving pre-installed walls and SCL (combined SBE \& EBS shaft construction)

Negligible movements were observed beyond a distance of $1 \cdot 5 \mathrm{H}$ from the shaft.

Three data points for the LPT Wimbledon (WIM) shaft showed relatively large settlements (greater than $0 \cdot 06 \% H$ ), marked as anomalies on Figure 16. Site records reported bulging of four caisson rings. As a result, the shaft construction method for the top section was changed from jacked precast segments to pre-cast segments. It is not clear whether these larger movements were associated with bulging of the jacked pre-cast segments.

The influence of the shaft diameter is evident in Figure 16. Smaller settlements were observed during excavation of the

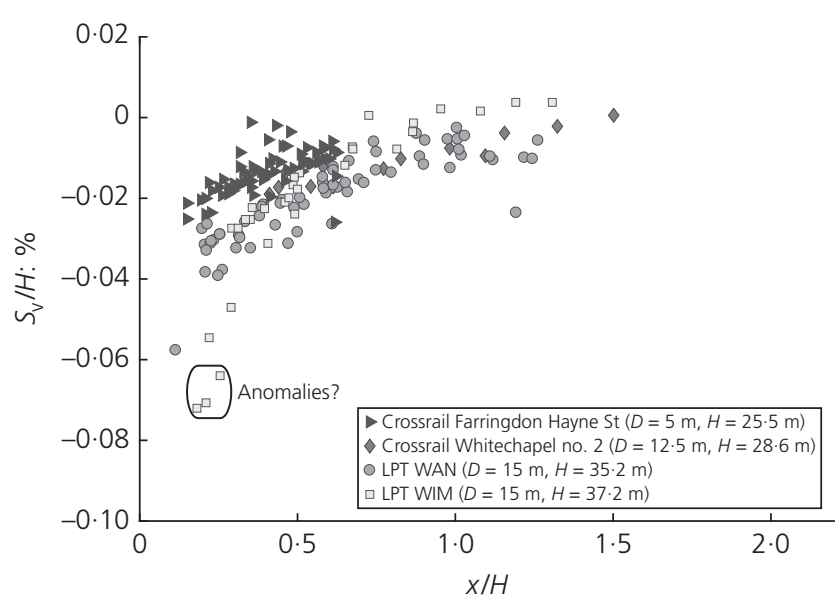

Figure 16. Field observations of settlements during excavation of dual-lined shafts involving jacked pre-cast segments and $\mathrm{SCL}$ (combined SBE \& EBS shaft construction) 
$5 \mathrm{~m}$ dia. shaft at Hayne Street compared with the other three shafts of diameter $12 \cdot 5-15 \mathrm{~m}$.

\section{Discussion and conclusion}

Until now, the limited number of well-documented case study shafts in London has made it difficult to investigate properly the parameters that influence ground movements during circular shaft construction. This paper had tried to address this uncertainty. Field observations of ground surface settlement were assembled from a number of circular shafts recently built for Crossrail, National Grid's LPT project and Transport for London's NLE. The geometry of the case study shafts ranged from $5 \mathrm{~m}$ to $30 \mathrm{~m}$ in diameter and $15 \mathrm{~m}$ to $44 \mathrm{~m}$ in depth. Two categories of shaft construction were identified. The first category, SBE, provided support to the soil using pre-installed walls before subsequent excavation of the shaft. For the second category, EBS, the shaft was excavated in sections, typically $1 \mathrm{~m}$ in height, before supporting the soil with the shaft lining (pre-cast segments or SCL). In some cases, the shaft was duallined using a combination of both shaft construction categories, SBE and EBS.

The field observations presented in Figures 11-16 give a good indication of the magnitude of settlement that can be expected during circular shaft construction in typical London Basin strata. For most of the case study shafts involving SBE construction, field observations of settlement were only available for the excavation phase (limited data were available during installation of the pre-installed walls). As a result, the settlements due to the installation of pre-installed walls and subsequent excavation of the shaft were presented separately in this paper. However, it is important that settlement assessments for SBE shaft construction should always consider the total settlement arising from the installation of pre-installed walls and subsequent excavation of the shaft. This is particularly important for SBE shaft construction adjacent to buried pipelines that cannot tolerate much strain.

The field observations show that settlements arising from the excavation of circular shafts are critically dependent on the method of shaft construction. Settlements arising from the installation of pre-installed walls may be in the region of $0.02 \% H$, provided a high quality of workmanship exists. Notwithstanding wall installation effects, there is little concern for SBE shaft construction in cases where the pre-installed shaft lining is constructed in stiff ground: very small settlements are generated and the overly conservative predictions currently used by designers are not required. However, some caution should be exercised for jacked pre-cast segments as relatively small excavations can generate greater movements than much larger diaphragm wall excavations. This may be due to a reduction of the in situ horizontal soil stress and stiffness caused by excavation ahead of the lead cutting ring. Settlement due to EBS shaft construction is potentially more significant: greater settlements are generated when the ground is temporarily exposed before the concurrent shaft lining is constructed.

The field observations also confirm that ground movements are influenced by the size of the shaft. For a given shaft construction method, smaller diameter shafts generated smaller settlements and larger diameter shafts generated greater settlements. Negligible settlements tended to occur beyond a distance of $1.0 \mathrm{H}$ to $1.5 \mathrm{H}$ from the shaft. However, the extent of the settlement profile will need to be assessed properly for shafts that are significantly different from those presented in this paper.

\section{Acknowledgements}

The authors would like to thank the Engineering and Physical Sciences Research Council (award reference 1220514) and Geotechnical Consulting Group for funding this research. They also express gratitude to Crossrail Limited, National Grid and Transport for London for their generous provision of vital shaft construction records and permission to publish the field data and site photographs. The support of Costain, Cementation Skanska, the Ferrovial Agroman Laing O'Rourke joint venture (FLO) and Geocisa UK is also gratefully acknowledged. In addition, special thanks are given to David Harris, John Davis, John Roseler, Professor Kenichi Soga, Dr Mehdi Alhaddad, Mike Black, Mohamad Alsedare, Neil Moss, Paul Braddish, Dr Phil Smith, Pietro Bologna, Dr Seda Torisu and Thomas Smith for their assistance with installing monitoring instruments and obtaining field measurements. The associated research data is available at https:/l doi.org/10.17863/CAM.22617.

\section{REFERENCES}

Clough G and O'Rourke T (1990) Construction induced movements of in-situ walls. Design and Performance of Earth Retaining Structures. ASCE, Reston, VA, USA, Geotechnical Special Publication 25, pp. 439-470.

Faustin NE (2017) Performance of Circular Shafts and Ground Behaviour during Construction. PhD thesis, University of Cambridge, Cambridge, UK.

Faustin E, Mair R, Elshafie M, Menkiti C and Black M (2017) Field measurements of ground movements associated with circular shaft construction. Proceedings of the 9th International Symposium on Geotechnical Aspects of Underground Construction in Soft Ground (IS-São Paulo) (Negro A and Cecílio MO (eds)). CRC Press, Leiden, the Netherlands, pp. 301-308.

GE (Google Earth) (2015) Eade Road 5130'27.56"N, 007’39.78"W, elevation 13M. See https://www.google.com/earth/ (accessed 20/08/2016).

GE (2017) Kennington 5129'01.11" N 006’38.38" W. See https:// www.google.com/earth/ (accessed 09/02/2017).

Menkiti C and Long M (2015) Consolidation settlements in Dublin Boulder Clay. In Geotechnical Engineering for Infrastructure and Development: XVI European Conference on Soil Mechanics and Geotechnical Engineering (Winter MG, Smith DM, Eldred PJL and Toll DG (eds)). ICE Publishing, London, UK, pp. 313-318.

Muramatsu M and Abe $\mathrm{Y}$ (1996) Considerations in shaft excavation and peripheral ground deformation. In Geotechnical Aspects of 
Underground Construction in Soft Ground (Mair R and Taylor R (eds)). Balkema, Rotterdam, the Netherlands, pp. 173-178.

New B and Bowers K (1994) Ground movement model validation at the Heathrow Express trial tunnel. In Proceedings of 7 th International Symposium Tunnelling '94. Chapman and Hall, London, UK, pp. 301-329.

NG (National Grid) (2015) London Power Tunnels Portfolio. National Grid, London, UK. See http://www.londonpowertunnels.co.uk/ portfolio/ (accessed 23/08/2016)
Schwamb T, Soga K, Elshafie MZEB and Mair RJ (2016)

Considerations for monitoring of deep circular excavations. Proceedings of the Institution of Civil Engineers-Geotechnical Engineering 169(6): 477-493, https://doi.org/10.1680/ jgeen.15.00063.

Wong RCKR and Kaiser PPK (1988) Behaviour of vertical shafts: reevaluation of model test results and evaluation of field measurements. Canadian Geotechnical Journal 25(2): $338-352$.

\section{How can you contribute?}

To discuss this paper, please email up to 500 words to the editor at journals@ice.org.uk. Your contribution will be forwarded to the author(s) for a reply and, if considered appropriate by the editorial board, it will be published as discussion in a future issue of the journal.

Proceedings journals rely entirely on contributions from the civil engineering profession (and allied disciplines). Information about how to submit your paper online is available at www.icevirtuallibrary.com/page/authors, where you will also find detailed author guidelines. 